eCommons@AKU

THE AGA KHAN UNIVERSITY

Department of Medicine

Section of Diabetes, Endocrinology and

Metabolism

Department of Medicine

May 2018

\title{
Sofosbuvir Causing Diabetes Mellitus: Is there a Link?
}

Sumerah Jabeen

Aga Khan University, sumerah.jabeen@aku.edu

Owais Rashid

Aga Khan University, owais.rashid@aku.edu

Saira Furqan

Aga Khan University, saira.furqan@aku.edu

Follow this and additional works at: https://ecommons.aku.edu/

pakistan_fhs_mc_med_diabet_endocrinol_metab

Part of the Endocrinology, Diabetes, and Metabolism Commons

\section{Recommended Citation}

Jabeen, S., Rashid, O., Furqan, S. (2018). Sofosbuvir Causing Diabetes Mellitus: Is there a Link?. JCPSP:Journal of the College of Physicians and Surgeons--Pakistan., 28(5), 414-414.

Available at: https://ecommons.aku.edu/pakistan_fhs_mc_med_diabet_endocrinol_metab/26 


\section{Sofosbuvir Causing Diabetes Mellitus: Is there a Link?}

Sir,

Chronic hepatitis $C$ infection affects 170 million individuals worldwide. Since the introduction of new oral direct acting antiviral (DAA) drugs, the treatment of chronic hepatitis $C$ infection has been revolutionised. ${ }^{1}$ Although metabolic derangements along with insulin resistance are widely recognised with $\mathrm{HCV}$ infection, there are few case reports of how treatment with the newer oral antiviral agents leads to diabetes in previously nondiabetic chronic hepatitis $\mathrm{C}$ infected patients, after successful eradication of the infection itself. ${ }^{2}$

Here, we describe a case of a 50-year female with a body mass index (BMI) of $32.8 \mathrm{~kg} / \mathrm{m}^{2}$ with chronic hepatitis $C$ virus infection, mixed genotype 3 and 6 , diagnosed and started on three drug regimens with sofosbuvir, $400 \mathrm{mg}$ QD, Daclatasvir Dihydrochloride, 60 $\mathrm{mg} \mathrm{QD}$, and Ribavarin $400 \mathrm{mg}$ TID. She achieved endof-treatment response (ETR) at 6 months but thereafter presented with history of progressive leg pains. On testing, her random blood sugar was $494 \mathrm{mg} / \mathrm{dl}$ with an anion gap of 12 and no urinary ketones. Prior to starting antiviral agents, her $\mathrm{HbA} 1 \mathrm{c}$ was $5.50 \%$ and three months post-treatment, her HbA1c was $11.40 \%$. Her $\mathrm{HbA} 1 \mathrm{c}$ pre- and post-treatment were done by our laboratory by immunoturbidity method and data from this laboratory is traceable to NGSP and is DCCT certified. There was no history of gestational diabetes mellitus (DM) or pre-diabetes, except that her father was a known diabetic. Other etiologies for her raised blood sugars were excluded, including exposure to certain drugs, pancreatitis or any ongoing acute infection.

In recent past, there has accumulated conflicting data on effects of oral DAAs with few studies favouring good glycemic control following treatment; whereas, others showing no effects on $\mathrm{HbA} 1 \mathrm{c}$ levels pre- and posttreatment. 3,4 Our patient did not have any comorbities or a pre-diabetic range $\mathrm{HbA} 1 \mathrm{c}$ level prior to treatment with DAAs and it was only after completion of treatment and achieving ETR that there was a sudden rise in $\mathrm{HbA} 1 \mathrm{c}$ levels. Therefore, we could not completely rule out the possibility that the DAAs might have led to overt hyperglycemia in our patient or this could simply be a coincidence. It is not possible to pinpoint the precipitating factor on the basis of just one case presented here. However, it provides food for thought for future studies on this subject.

\section{REFERENCES}

1. Bose SK, Ray R. Hepatitis $C$ virus infection and insulin resistance. World J Diabetes 2014; 5: 52-58.

2. Premji R, Roopnarinesingh N, Qazi N, Nylen ES. New-onset diabetes mellitus with exposure to ledipasvir and sofosbuvir. J Investig Med High Impact Case Rep 2015; 3: 2324709615623300.

3. Stine JG, Wynter JA, Niccum B, Kelly V, Caldwell SH, Shah NL. Effect of treatment with direct acting antiviral on glycemic control in patients with diabetes mellitus and chronic hepatitis C. Ann Hepatol 2017; 16:2.

4. Morales AL, Junga $Z$, Singla MB, Sjogren M, Torres D. Hepatitis $C$ eradication with sofosbuvir leads to significant metabolic changes. World J Hepatology. 2016; 8:1557.

Sumerah Jabeen, Owais Rashid and Saira Furqan Department of Endocrinology, The Aga Khan University Hospital, Karachi.

Correspondence: Dr. Sumerah Jabeen, Endocrine Fellow, The Aga Khan University Hospital, Stadium Road, P. O. Box 3500, Karachi.

E-mail: sumerah.jabeen@aku.edu

Received: December 27, 2017; Accepted: Febuary 17, 2018. 